\title{
生理的なタンパク質間相互作用の解析を可能にする細胞内光クロスリンク技術
}

\author{
樋野展正
}

\section{A Method for Protein Photo-cross-linking in Living Cells Facilitating Analysis of Physiological Interactions of Proteins}

\author{
Nobumasa Hino \\ Graduate School of Pharmaceutical Sciences, Osaka University; 1-6 Yamadaoka, Suita, Osaka 565-0871, Japan.
}

(Received June 29, 2015)

\begin{abstract}
In living cells, most proteins form complexes with other proteins to exert their functions. Since protein functions are regulated in response to changes in the cellular environment, the components of the complexes can vary; therefore, proteins often interact in a weak and transient manner. To capture such labile protein interactions, we have developed a method for photo-cross-linking of proteins directly interacting in mammalian cells; this method involves expansion of the genetic code and site-specific incorporation of photoreactive amino acids into proteins. Upon cross-linking, protein complexes are stabilized by a covalent bond and can be readily isolated from cell extracts without the problems usually associated with simple affinity purification methods such as co-immunoprecipitation. Photo-cross-linkers have another benefit: they react exclusively with molecules within a range defined by the linker length. This property becomes useful for determining the binding interface of two proteins because the linkers can be introduced in a site-directed manner with our method. In this review, we first describe the expansion of the genetic code of mammalian cells for the incorporation of non-natural amino acids into proteins. Then, we introduce our recent applications and developments of the crosslinking method: identification of intracellular binding partners of the signaling protein growth factor receptor binding protein 2; analysis of the binding between membrane proteins on the cell surface; and a novel photoreactive amino acid that enables wide-ranging photo-cross-linking.
\end{abstract}

Key words — - photo-cross-linking; non-natural amino acid; expanded genetic code; protein-protein interaction

\section{1. はじめに}

生細胞内において多くのタンパク質は他のタンパ ク質と複合体を形成することでその機能を発揮して いる. 一方で, タンパク質の機能は種々の細胞外刺 激や環境の変化に応じて正確に調節されているた め, 複合体の構成因子はその都度変化する。 それゆ え, 生理的なタンパク質間相互作用を解析するに は，細胞内で実際に形成されているタンパク質複合 体をいかに単離するかが鍵となる。 タンパク質複合 体の解析には研究対象のタンパク質に対する抗体を 用いた共免疫沈降法を用いるのが一般的である。す なわち，抗体の持つ高い特異性を利用して細胞抽出 液から目的のタンパク質複合体を高純度に精製し,

大阪大学大学院薬学研究科（=565-0871 大阪府吹田市 山田丘 1-6)

e-mail: hino@phs.osaka-u.ac.jp

本総説は, 平成 26 年度日本薬学会近畿支部奨励賞（生 物系薬学）の受賞を記念して記述したものである.
その構成成分を質量分析によって同定するという戦 略である。しかしながら，この手法は複合体が十分 に安定である場合にのみ適用可能であり，また，単 離したタンパク質複合体が実際に細胞内で形成され たものか, あるいは, 細胞から抽出された後に試験 管内で形成されたものかについては逐一検証する必 要があるという問題も指摘されている. ${ }^{1)}$

クロスリンカーを用いればタンパク質複合体を安 定化することができる. しかしながら，従来の低分 子クロスリンカーはあらゆるタンパク質をランダム に修飾してしまうという問題があり, 細胞内におけ るタンパク質間相互作用の解析への応用は限定的で あった。筆者らは, 2005 年に, 光クロスリンカー として機能する「非天然型アミノ酸」を哺乳類細胞 内でタンパク質に部位特異的に導入することに成功 し，また，その細胞に光を照射することで相互作用 するタンパク質との間に共有結合を形成させる「細 胞内光クロスリンク技術」の開発に成功した（Fig. 


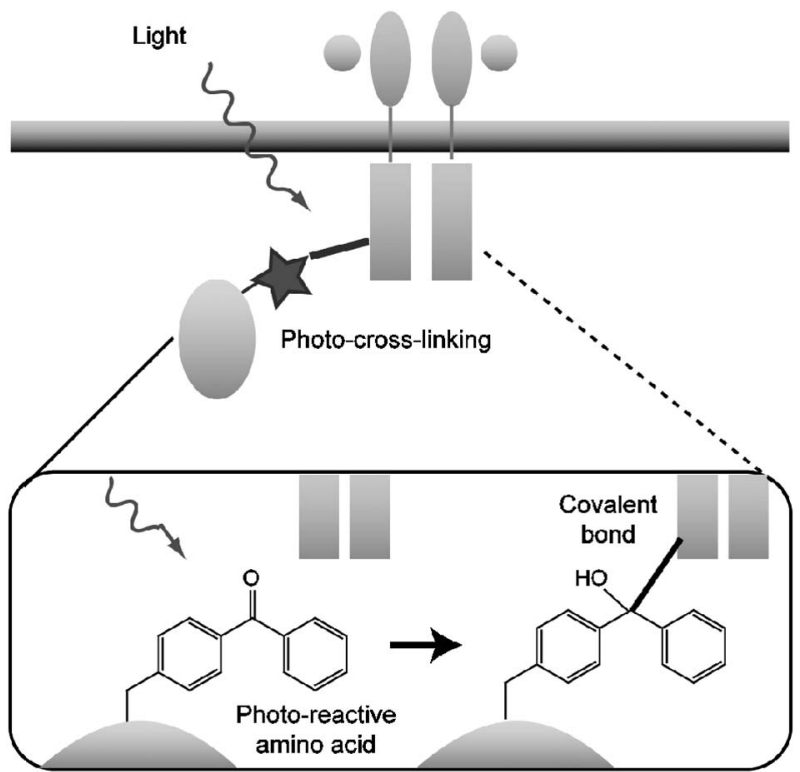

Fig. 1. Illustration of Protein Photo-cross-linking in Living Cells

Upon photo-irradiation, a photo-reactive amino acid at the protein surface reacts with a nearby molecule and forms a covalent bond.

1).2)これにより, 生細胞内で実際に生じている夕 ンパク質複合体を安定化し，単離・解析することが 可能になることから，この技術は共免疫沈降法の欠 点を補完するツールとして非常に有用であると考え られる。ささらに，クロスリンカーには自身のリン カー長に規定される範囲内に近接した分子とだけ反 応するという性質がある。筆者らの技術を用いれ ば，光クロスリンカーをタンパク質の望みの部位に 導入できるので，その導入箇所とクロスリンク形成 の有無の関係を調べることで 2 つタンパク質の相 互作用表面について解析することも可能である. 本 総説では，まずこの技術の原理について概説し，さ らに，この技術を用いた細胞内相互作用因子の同定 例及び膜タンパク質の相互作用様式の解析例につい て紹介する.

\section{2. 拡張遺伝暗号とタンパク質への部位特異的な} 非天然型アミノ酸導入

細胞内光クロスリンク技術は, 光クロスリンカー として機能する非天然型アミノ酸を細胞内でタンパ ク質に部位特異的に導入する手法に立脚している.

これは，哺乳類細胞の持つ遺伝暗号を拡張し，本来 アミノ酸をコードしていないコドン（例えば終止コ ドンの 1 つであるUAG コドン）に対して非天然型 アミノ酸を特異的に割り当てることで達成される. 遺伝暗号拡張（genetic code expansion）は，2001 年に米 Scripps 研究所の Schultz らによって大腸菌 細胞で達成されたのを皮切りに，ついで 2002 年に は理化学研究所の横山, 坂本らによって哺乳類細胞 で，その後，酵母細胞や昆虫細胞，線虫においても 達成され，様々な非天然型アミノ酸の導入に用いら れている. ${ }^{3-7)}$

UAG コドンに対して非天然型アミノ酸を導入す るには，UAGコドンと対合する tRNA（以下，サ プレッサー tRNA とする）と，この tRNA に非天 然型アミノ酸を特異的に付加するよう改変されたア ミノアシル tRNA 合成酵素（aminoacyl-tRNA synthetase；aaRS）を細胞内にともに発現させればよ い.この際，望みの部位を UAG コドンに置換した 標的タンパク質の遺伝子を同時に発現させること で，非天然型アミノ酸を部位特異的に含むタンパク 質が合成されるという仕組みである [ Fig. $2(\mathrm{~A})] .{ }^{4,8)}$ ただし, 非天然型アミノ酸をUAGコド ンに特異的に割り当てるには, サプレッサー tRNA が宿主細胞の持つすべての a RS に認識されないこ と, また, 改変型 aaRS が宿主細胞のすべての tRNA や細胞内に存在するアミノ酸を認識しないこ とが必須の条件となる，このような関係性は「直交 性（orthogonality）」と呼ばれている，哺乳類細胞 において直交性を満たす tRNA と aaRS のペアとし ては，真正細菌のサプレッサーチロシン tRNA (sup-tRNA ${ }^{\mathrm{Tyr}}$ )・チロシル tRNA 合成酵素（TyrRS） のペアやある種の古細菌が持つピロリジンという特 殊なアミノ酸を認識するピロリジン tRNA $\left(\mathrm{tRNA}^{\mathrm{Pyl}}\right)$ ・ピロリジル tRNA 合成酵素のペアが主 に利用されている. 4,9-11) さらに，多様な側鎖構造を 持つ非天然型アミノ酸のそれぞれを特異的に認識し て自身の基質とする改変型 TyrRS や改変型 PylRS の開発が精力的に進められた結果，現在では，様々 なフェニルアラニン誘導体やリジン誘導体をタンパ ク質に導入することができるようになってい

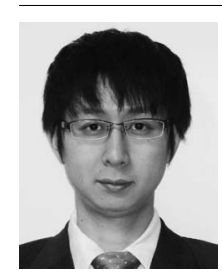

樋野展正
大阪大学大学院薬学研究科生命情報解 析学分野助教. 2000 年大阪大学薬学部 製薬化学科卒業, 2002 年大阪大学大学 院薬学研究科博士前期課程修了, 2005 年東京大学大学院理学系研究科博士後 期課程修了 (理学博士), 2005 年理化 学研究所リサーチアソシエイト, 特別 研究員, 研究員を経て 2012 年より現職. 
A Bacterial suppressor tRNA ${ }^{\text {Tyr }}$
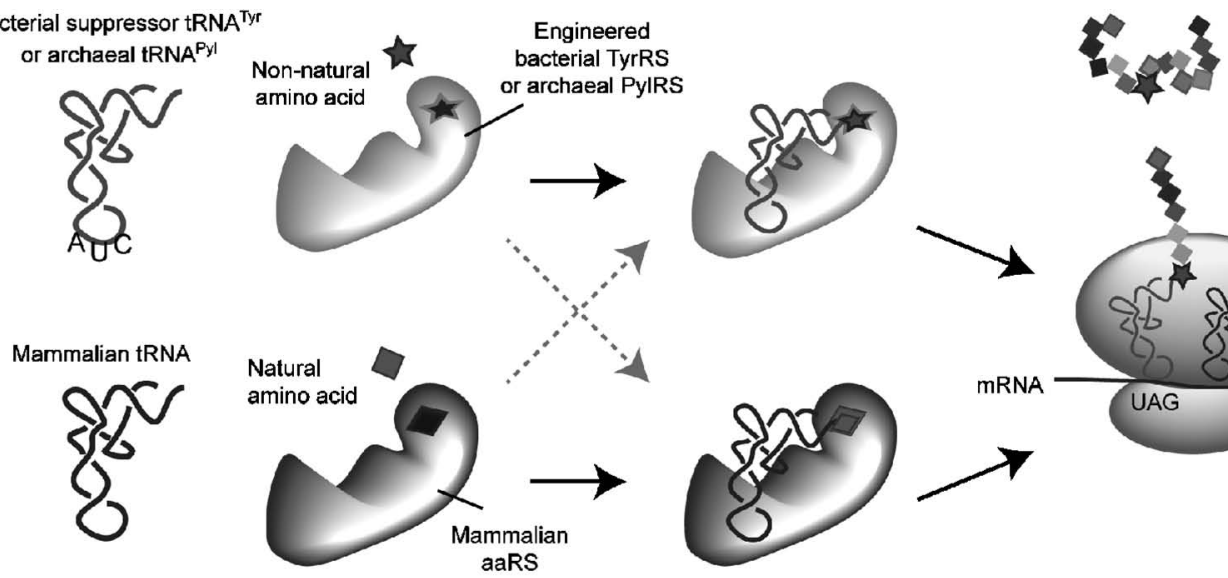

Protein with

non-natural

amino acid

aaRS

B
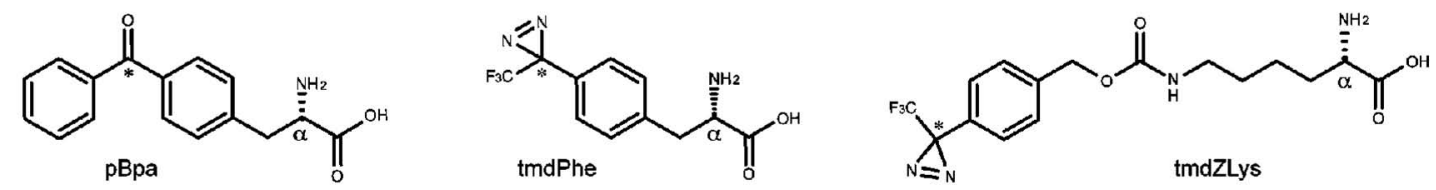

Fig. 2. Site-specific Incorporation of Non-natural Amino Acids into Proteins in Mammalian Cells

(A) An orthogonal pair of suppressor tRNA and engineered aminoacyl tRNA synthetase assigns a non-natural amino acid to the UAG codon. (B) Structures of photo-reactive amino acids; $\alpha$ and $*$ represent the $\alpha$-carbon and photoreaction center, respectively.

る. ${ }^{12,13)}$

\section{3. 細胞内光クロスリンク技術}

上記の遺伝暗号拡張技術を用いて，筆者らは，光 クロスリンカーとして機能する 3 つ非天然型アミ ノ酸 $p$-benzoyl-L-phenylalanine $(p \mathrm{Bpa}), p$-trifluoromethyl-diazirinyl-L-phenylalanine (tmdPhe), $N \varepsilon$ [ ( (4- (3- (trifluoromethyl) -3H-diazirin-3-yl) -benzyl) oxy) carbonyl]-L-lysine （tmdZLys）を哺乳類培養細 胞内でタンパク質に導入することに成功した [Fig. $2(\mathrm{~B})] .^{2,14,15)}$ これらのアミノ酸は光反応性を持つべ ンゾフェノン骨格若しくはジアジリン骨格を有して おり, $360 \mathrm{~nm}$ 付近の波長を持つ光照射に応じて活 性化し，近傍の分子と共有結合を形成するという特 徵を持っている，そこで，これらのアミノ酸を導入 したタンパク質を細胞内に発現させ，その細胞に光 を照射した場合に，相互作用因子との間にクロスリ ンクが形成されるかについて調べることにした. ${ }^{2}$

光クロスリンカーとしては $p \mathrm{Bpa}$ を選択し，その 導入標的としては様々なシグナル伝達を媒介する夕 ンパク質である growth factor receptor-bound protein 2 (GRB2) を選択した。 GRB2 はリン酸化チロ シンを含む配列に結合する SH2 ドメインとプロリ ンリッチ配列に結合する 2 つの SH3 ドメインから 構成されるが，この SH2 ドメインにはリン酸化さ
れた EGF 受容体 (epidermal growth factor receptor；EGFR）が結合することが知られている。 そこ で, GRB2 の SH2 ドメインとリン酸化リガンドの 複合体構造から，リガンドの近傍に位置し，かつリ ガンドとの相互作用には関与しないと予想される 111 番目のロイシン残基を $p \mathrm{Bpa}$ に置換し，EGFR とのクロスリンクを試みた $[\mathrm{Fig} .3(\mathrm{~A})]$ 。 チャイ ニーズハムスター卵巣細胞に FLAG タグを付加し た野生型 GRB2［GRB2（WT）］若しくは $p$ Bpa を 導入した GRB2 変異体 $[\mathrm{GRB} 2(\mathrm{~L} 111 p \mathrm{Bpa})]$, 及 び，相互作用因子である EGFR をともに発現させ た.この細胞に EGF を添加して EGFR のリン酸化 を誘導した後， $365 \mathrm{~nm}$ の波長を持つ光を照射した ところ，GRB2（L111pBpa）を発現させた場合に のみ約 $200 \mathrm{kDa}$ の分子量を持つタンパク質成分が 生じることがわかった [Fig. 3(B)]。この産物は, EGF 刺激及び光照射に応じて生じたこと，また， EGFR 及び FLAG タグに対する抗体のどちらを用 いた場合でも検出されたこと, さらに, GRB2の分 子量 $25 \mathrm{kDa}$ と EGFR の分子量 $170 \mathrm{kDa}$ を足し合わ せた $200 \mathrm{kDa}$ 程度の分子量を持つことから，GRB2 と EGFR のクロスリンク複合体であると考えられ た．以上のことより，光クロスリンカーとして機能 する非天然型アミノ酸をタンパク質に導入すること 

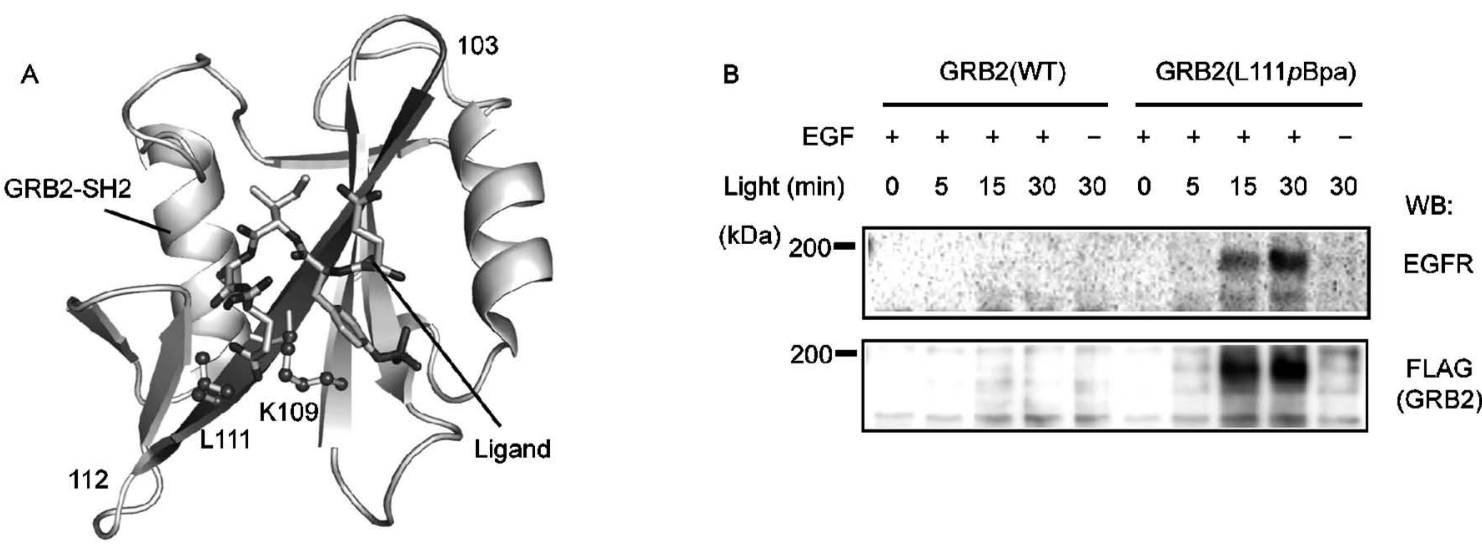

Fig. 3. Photo-cross-linking between Growth Factor Receptor-bound Protein 2 (GRB2) and the Epidermal Growth Factor (EGF) Receptor (EGFR)

(A) Crystal structure of the SH2 domain of GRB2 (cartoon model) binding with a phosphorylated ligand (stick model). The leucine residue at position 111 and the lysine residue at position 109 are shown in ball-and-stick representation. The $\beta$-strand of GRB2 extending across the bound ligand (positions 103-112) is shown in dark gray. (B) Analysis of photo-cross-linking between wild-type (WT) GRB2 or GRB2 containing $p$ Bpa and EGFR under the indicated conditions. The cross-linked products were detected by western blotting (WB) with antibodies to EGFR and FLAG tag.

で，細胞内におけるタンパク質間相互作用を捉えら れることが示された.

\section{GRB2 の新規相互作用因子の同定}

GRB2 は SH2 ドメインを介して EGFR 以外にも 様々なリン酸化タンパク質と相互作用することが知 られている. そこで, 細胞にリン酸化シグナルを惹 起した際に GRB2 の SH2 ドメインと結合するタン パク質を細胞内光クロスリンク技術を用いて網羅的 に同定することを試みた. ${ }^{14)}$ 光クロスリンク能を持 つ非天然型アミノ酸としては tmdPhe を用いた [Fig. 2(B)].この理由として, tmdPhe は前述の $p \mathrm{Bpa}$ よりもサイズが小さく, また, クロスリンク 反応に要する時間が短いため, 非天然型アミノ酸の 導入による相互作用因子の結合阻害を軽減できると 同時に，一過的にリン酸化修飾を受けたタンパク質 との相互作用を捉えるのに有効であることが期待さ れたためである.

まず，GRB2 の SH2 ドメインに対する tmdPhe の導入箇所について既知の相互作用因子である EGFR 及び SHC とのクロスリンク形成を指標に検 討したところ，109番目のリジン残基の位置に tmdPhe を導入することが最適であることがわかっ た [Fig. 3(A)]. そこで, この tmdPhe 導入 GRB2 変異体と EGFR $293 \mathrm{c} 18$ 細胞内に共発現させ, EGF 刺激後, $365 \mathrm{~nm}$ の光に暴露した際に, GRB2 変異体とクロスリンクする内在性のタンパク質を網 羅的に探索した。 クロスリンク複合体は精製過程で も安定に存在するため, 最終精製産物には通常の複
合体よりも多く含まれているはずである，そこで, 光照射をした細胞群と光照射をしない細胞群のそれ ぞれから GRB2 複合体を精製し，光照射群に多く 含まれるタンパク質を比較定量性に優れた質量分析 手法である stable isotopic labeling of amino acids and cell culture (SILAC) 法によって同定した。 そ の結果, 共発現した EGFR や既知の相互作用因子 である SHP2 に加え, EGF 刺激下でリン酸化され るという報告のある GIT1 やAF6，さらには，これ まで機能的な相関が全く知られていなかつた複数の RNA 結合性タンパク質を GRB2 の SH2 ドメイン に結合する新規相互作用因子として同定することに 成功した。一方で, GRB2 の SH3 ドメインと結合 することが知られている SOS や Dynamin といつた 因子は, 光照射群, 非照射群から同程度に検出され たことから，今回用いた GRB2 変異体と相互作用 はするものの, クロスリンクはしないという結果が 得られた。これらの結果は, クロスリンカーとして 機能する非天然型アミノ酸を部位特異的に導入する ことで, タンパク質の特定のドメインと細胞内でダ イレクトに結合する因子を特異的に同定できること を示している.

\section{5. タンパク質複合体構造の検証}

タンパク質に部位特異的に光クロスリンカーを導 入できるというこの技術の利点は, 細胞内における タンパク質複合体の相互作用様式について調べる上 でも有用である. 1 回膜貫通型タンパク質である receptor activity modifying protein 2 (RAMP2) は 
A

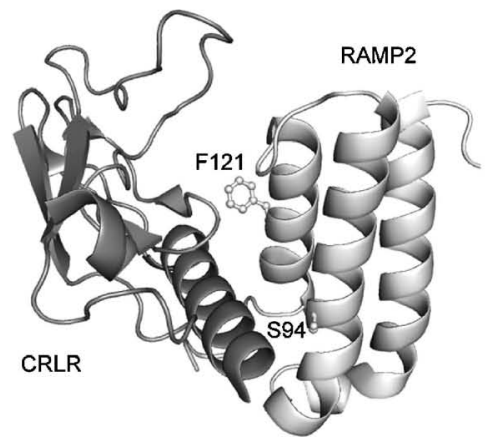

B

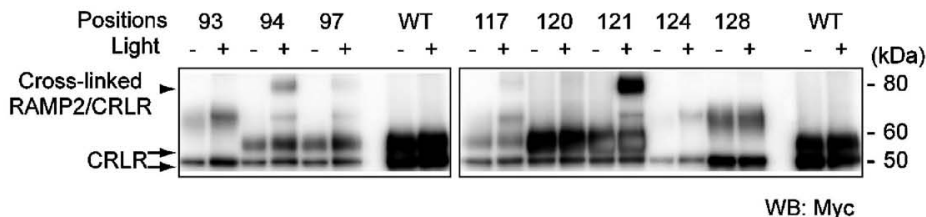

Fig. 4. Photo-cross-linking of Receptor Activity Modifying Protein 2(RAMP2) Containing $p$ Bpa with Calcitonin-receptor-like Receptor (CRLR) on the Cell Surface

(A) Crystal structure of the RAMP2/CRLR extracellular domain complex. The serine residue at position 94 and the phenylalanine residue at position 121 are shown in ball-and-stick representation. (B) Western blot (WB) analysis of photo-cross-linking between RAMP2 variants containing $p$ Bpa at the indicated positions and Myc-tagged CRLR. Cross-linked and non-cross-linked CRLR were detected by anti-Myc antibody.

クラス B GPCR であるカルシトニン受容体様受容 体 (calcitonin-receptor-like receptor; CRLR) と互 いの細胞外ドメインを介して相互作用するが，細胞 膜上ではこのへテロ二量体が血管拡張性ペプチドで あるアドレノメデュリンの受容体として機能するこ とが知られている．筆者らは，これらのタンパク質 の細胞外ドメインを in vitroでそれぞれ合成し，複 合体を形成させた上で，その結晶構造を解析するこ とに成功した [Fig. 4(A)]。 ${ }^{16)}$ そこで，RAMP2 と CRLR を生細胞膜上に全長のタンパク質として発 現させた場合に同様の複合体構造を取り得るのかど うかについて, 光クロスリンク実験により検証する ことにした。前述のように, 光クロスリンカーは, 相互作用タンパク質の表面に位置するアミノ酸残基 が近傍に存在する場合にのみ反応して共有結合を形 成する，そこで，既に明らかにした結晶構造を基に， CRLR との相互作用表面を形成する RAMP2 の 2 本の $\alpha$ ヘリックス構造中に存在するいずれかの残 基を $p$ Bpa に置換した計 8 種類の変異体を作製し,

CRLR とクロスリンクする箇所について調べた. その結果，予想された通り，結晶構造中で CRLR の近傍に存在し，かつ，相互作用自体を阻害しない と考えられる 97 番目あるいは 121 番目の位置に $p \mathrm{Bpa}$ が導入された場合にのみクロスリンクが形成 されることがわかつた [Figs. 4(A) and (B)].こ のことは, 本研究により得られた結晶構造が, 細胞 膜上で実際に形成される複合体の構造を反映したも のであることを示している. 同様の手法は, 細胞膜 上で形成されるインターロイキン -5 とその受容体 の複合体構造及び CD38 抗原のダイマー構造の検証
に用いられ，また，CRF 受容体とそのリガンドで あるウロコルチン-1 の相互作用部位の同定にも応 用されている. ${ }^{17-19)}$

\section{6. 広域反応性光クロスリンカーの開発}

これまでの研究で光クロスリンカーとして用いた 非天然型アミノ酸 $p \mathrm{Bpa}, \mathrm{tmdPhe}$ は, $\alpha$ 炭素から反 応中心までの距離が $7 \AA$ 程度であった。すなわ ち, 原理上はタンパク質の主鎖から $7 \AA$ 程度の距 離に相互作用因子が近接しないとクロスリンクが形 成されないことになる。実際に，複合体構造を基に クロスリンクを形成させるのに適していると思われ る位置にこれらのクロスリンカーを導入しても，効 率のよいクロスリンクが確認されるのは 10 カ所中 2 力所程度である。これを解決するため， $\alpha$ 炭素か ら反応中心までの距離が $15 \AA$ である非天然型アミ ノ酸 tmdZLys を新たに設計・合成した [Fig. 2 (B) ]。このアミノ酸は，長い側鎖を持つアミノ酸 を導入可能な改変型ピロリジル tRNA 合成酵素と ピロリジン tRNA のペアを利用することで，哺乳 類培養細胞内でタンパク質に比較的高い効率で導入 することが可能であった，そこで，前述した GRB2 の SH2 ドメインに対し, その結晶構造中でリガン ドに直交するように伸びる $\beta$ シート上の各残基 (103-112 番目のアミノ酸残基) と置換する形で tmdZLys を導入した [Fig. 3(A)]。これらのGRB2 変異体と $\mathrm{EGF}$ 受容体とのクロスリンク実験を行っ たところ， $p$ Bpa や tmdPhe ではリガンドのすぐ近 くに導入された 2 変異体でのみ効率よくクロスリン クが形成されたのに対し, ${ }^{2,14)}$ tmdZLys を用いた場 合には 10 力所中 5 力所という広範囲の導入箇所に 


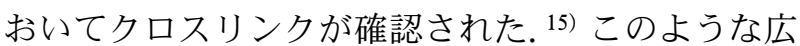
域反応性を持つ tmdZLys を利用することで，最適 なクロスリンカー導入部位の探索が容易になると同 時に，結合様式の異なる様々な相互作用因子の同定 にも役立つと考えられる。

\section{7. おわりに}

質量分析機器の飛躍的な高感度化やゲノムデータ ベースの充実により，現在では，試料中に含まれる ごくわずかなタンパク質でも同定することが可能に なっている．これに伴い，共免疫沈降実験により同 定される相互作用タンパク質の候補も膨大なものと なることが予想され，大量の夾雑物の中から生理的 な相互作用因子を選択的に同定するための技術が求 められている. また，タンパク質複合体の構造解析 においても, 細胞外で再構成された複合体の構造 が，細胞内における複合体構造を反映するのかどう かについては常に議論されるところである，筆者ら の開発した細胞内光クロスリンク技術は, 細胞内で 実際に生じているタンパク質複合体を対象として解 析できる特長を持つことから，これらの問題を解決 する 1 つのツールとして有用であると考えられる. また，クロスリンクによって複合体を安定化できる という利点は，高濃度の塩や界面活性剂といつた強 い溶出条件を必要とする膜タンパク質や核内タンパ ク質の相互作用解析に特に威力を発揮すると考えら れ，今後その活用の幅が広がることが期待される.

一方で，この技術についてはいまだいくつかの解 決すべき課題が残つている.1つめは, タンパク質 に対する非天然型アミノ酸の導入効率である．終止 コドンの 1 つであるUAG コドンに対して非天然型 アミノ酸を割り当てる場合，リボソーム上では，本 来このコドンに結合して翻訳を終結させる eRF1 と 外来性に発現させたサプレッサー tRNA が常に競 合している。 そのため，UAGコドンに対する非天 然型アミノ酸導入効率は $20 \%$ 程度に留まることが 多い。実は，大腸菌では 2 つの翻訳終結因子 RF1 (UAG コドンとUAA コドンを認識)，RF2（UAA コドンとUGA コドンを認識）のうち前者を欠損さ せることによって，非天然型アミノ酸の導入効率を $100 \%$ にすことが実現している。 ${ }^{20)}$ 大腸菌ではそ もそもUAG コドンの使用率が低いということもあ るのだが，このようにして作製された RF1 欠損大 腸菌株では，UAG コドンは非天然型アミノ酸用の
コドンとして再定義されている，しかしながら，哺 乳類細胞では eRF1 という 1 つの翻訳終結因子が 3 つの終止コドンを認識すること，また，3つの終止 コドンがほぼ均等に用いられていることから大腸菌 と同様の戦略を取ることが難しい。これまでに， siRNA による eRF1 のノックダウンや, ${ }^{21)} \mathrm{UAA}$ 及 び UGA コドンのみを認識する eRF1 変異体の過剩 発現によって UAG コドンに対する非天然型アミノ 酸導入効率の向上が試みられているが, ${ }^{22)}$ 根本的な 解決には全く新しいメカニズムによる UAG コドン の再定義が必要であると考えられる.

もう 1 つの課題は，非天然型アミノ酸を導入する ための宿主細胞の問題である。これまでの哺乳類細 胞を用いた研究では，アミノアシル tRNA 合成酵 素及びサプレッサーtRNA の遺伝子をプラスミド ベクターに搭載して細胞内に導入しているケースが ほとんどである。しかしながら，例えば組織特異的 に発現するタンパク質の相互作用を調べたい場合に は，その組織に由来する初代培養細胞などを用いた 解析が必要になるが，プラスミドベクターによる遺 伝子導入を許容するのは限られた細胞株のみであ る. 近年, レンチウイルスベクターやバキュロウイ ルスベクターを用いた遺伝子導入によって，いくつ かの細胞内で非天然型アミノ酸をタンパク質に導入 することが可能であるとの報告がなされた. ${ }^{23,24)}$ 今 後はより汎用性の高いアデノウイルスベクターやア デノ随伴ウイルスベクターを用いた非天然型アミノ 酸導入法の開発が期待される.

謝辞 本研究は, 大阪大学大学院薬学研究科生 命情報解析学分野並びに理化学研究所生命分子シス テム基盤研究領域で行われた研究であり，ご指導を 賜りました土井健史教授，横山茂之領域長，坂本健 作チームリーダーに心より感謝いたします。また, 研究を遂行するにあたり多大なご支援を頂きました 共同研究者の先生方, 研究員の皆様, 並びに学生の 皆様に感謝いたします。

利益相反＼cjkstart開示すべき利益相反はない.

\section{REFERENCES}

1) Markham K., Bai Y., Schmitt-Ulms G., Anal. Bioanal. Chem., 389, 461-473 (2007). 
2) Hino N., Okazaki Y., Kobayashi T., Hayashi A., Sakamoto K., Yokoyama S., Nat. Methods, 2, 201-206 (2005).

3) Wang L., Brock A., Herberich B., Schultz P. G., Science, 292, 498-500 (2001).

4) Sakamoto K., Hayashi A., Sakamoto A., Kiga D., Nakayama H., Soma A., Kobayashi T., Kitabatake M., Takio K., Saito K., Shirouzu M., Hirao I., Yokoyama S., Nucleic Acids Res., 30, 4692-4699 (2002).

5) Chin J. W., Cropp T. A., Anderson J. C., Mukherji M., Zhang Z., Schultz P. G., Science, 301, 964-967 (2003).

6) Mukai T., Wakiyama M., Sakamoto K., Yokoyama S., Protein Sci., 19, 440-448 (2010).

7) Greiss S., Chin J. W., J. Am. Chem. Soc., 133, 14196-14199 (2011).

8) Hino N., Hayashi A., Sakamoto K., Yokoyama S., Nat. Protoc., 1, 2957-2962 (2006).

9) Liu W., Brock A., Chen S., Chen S., Schultz P. G., Nat. Methods, 4, 239-244 (2007).

10) Mukai T., Kobayashi T., Hino N., Yanagisawa T., Sakamoto K., Yokoyama S., Biochem. Biophys. Res. Commun., 371, 818-822 (2008).

11) Chen P. R., Groff D., Guo J., Ou W., Cellitti S., Geierstanger B. H., Schultz P. G., Angew. Chem. Int. Ed. Engl., 48, 4052-4055 (2009).

12) Dumas A., Lercher L., Spicer C. D., Davis B. G., Chem. Sci., 6, 50-69 (2015).

13) Hino N., Sakamoto K., Yokoyama S., Methods Mol. Biol., 794, 215-228 (2012).

14) Hino N., Oyama M., Sato A., Mukai T., Iraha F., Hayashi A., Kozuka-Hata H., Yamamoto T., Yokoyama S., Sakamoto K., J. Mol. Biol., 406, 343-353 (2011).

15) Yanagisawa T., Hino N., Iraha F., Mukai T.,
Sakamoto K., Yokoyama, S., Mol. Biosyst., 8, 1131-1135 (2012).

16) Kusano S., Kukimoto-Niino M., Hino N., Ohsawa N., Okuda K., Sakamoto K., Shirouzu M., Shindo T., Yokoyama S., Protein Sci., 21, 199-210 (2012).

17) Kusano S., Kukimoto-Niino M., Hino N., Ohsawa N., Ikutani M., Takaki S., Sakamoto K., Hara-Yokoyama M., Shirouzu M., Takatsu K., Yokoyama S., Protein Sci., 21, 850-864 (2012).

18) Hara-Yokoyama M., Kukimoto-Niino M., Terasawa K., Harumiya S., Podyma-Inoue K. A., Hino N., Sakamoto K., Itoh S., Hashii N., Hiruta Y., Kawasaki N., Mishima-Tsumagari C., Kaitsu Y., Matsumoto T., Wakiyama M., Shirouzu M., Kasama T., Takayanagi H., Utsunomiya-Tate N., Takatsu K., Katada T., Hirabayashi Y., Yokoyama S., Yanagishita M., Structure, 20, 1585-1595 (2012).

19) Coin I., Katritch V., Sun T., Xiang Z., Siu F. Y., Beyermann M., Stevens R. C., Wang L., Cell, 155, 1258-1269 (2013).

20) Mukai T., Hayashi A., Iraha F., Sato A., Ohtake K., Yokoyama S., Sakamoto K., Nucleic Acids Res., 38, 8188-8195 (2010) .

21) Janzen D. M., Geballe A. P., Nucleic Acids Res., 32, 4491-4502 (2004).

22) Schmied W. H., Elsässer S. J., Uttamapinant C., Chin J. W., J. Am. Chem. Soc., 136, 15577-15583 (2014).

23) Shen B., Xiang Z., Miller B., Louie G., Wang W., Noel J. P., Gage F. H., Wang L., Stem Cells, 29, 1231-1240 (2011).

24) Chatterjee A., Xiao H., Bollong M., Ai H.W., Schultz P. G., Proc. Natl. Acad. Sci. USA, 110, 11803-11808 (2013). 